\title{
Evidence Based Medicine and Acupuncture (Dry Needling Stimulation) Today
}

\author{
Hegyi Gabriella*, MátéÁgnes, SzőkeHenrik and PetrovicsGabor \\ Faculty of Health Sciences, University of Pecs, Hungary
}

Submission: February 13, 2017; Published: June 13, 2017

*Corresponding author: Hegyi Gabriella, University of Pecs, Faculty of Health Sciences, Doctorate School, 7463 Pecs, Vorosmarty u. 4, Hungary, Email: drhegyi@hu.inter.net

\section{Introduction and definition}

Acupuncture ('dry needling') is one of the basic aspects of Traditional Chinese Medicine (TCM). Its classical base is presented by the "principle of energy flow system", the recognition of the channels (in other words: meridians) and the points of mechanical stimulus, namely the puncture points - acupuncture points - on which the former is based. The application of this principle can be carried out by mechanical stimulus: needle puncture, massage, temperature stimulus, vacuum based suction, as well as by ultrasound, laser, etc. In China it has been known for centuries about different herbs on which meridian they are effective and whether they belong to the type of yin or yang. So the knowledge of channels and points was also taken into consideration in Chinese phototherapy. In the diagnostic process the examination of the pulse plays an important role: by touching the arteriaradialis on the wrist with three fingers both on the surface and deeply, valuable information is received on the organs representing the twelve main meridians.

We can say that we are talking about a diagnostic and therapeutic whole body complex system based on a unitary theoretic foundation, which is consistent in itself. Traditional Chinese Medicine has already put down all these in writing in its 2600-year-old basic literature known as 'The Yellow Emperor's Classic of Internal Medicine', which is the most important professional literature even today and was extended later. It is also important to mention the point system of the ear, Yamamoto New Scalp Acupuncture system on scull - as Microsystems - acupuncture, which were only discovered a few decades ago, since '... meridians meet on the external ear' - as the above mentioned basic literature says. Throughout the acupuncture process extremely tiny filiform needles are put into certain so called 'acupuncture points' under the surface of the skin. The anatomical situation of a point is an entity, which is based on classical descriptions, empirical, today's biophysical measurements and new knowledge.

\section{Basic questions}

A few questions - already answered and still unanswered are waiting to be clarified:

-Do 'acupuncture points' really exist? What is a 'meridian' and how can it be explained in the classic synonym system?

- What is the essence of mechanical peripheral stimulus, the nervous and neurohumoral mechanism mediating acupuncture (e.g. pain-killing)?

- Is there an acceptable and relevant professional literature proving the efficiency of clinical acupuncture?

To the 1st question:

Do 'acupuncture points and meridians' really exist?

Is it more efficient to treat an acupuncture point already known than to place the needle into a sham acupuncture point? By examining the efficiency of acupunctural pain-killing, B Pomeranz [1] came to the conclusion that pains induced in acute, laboratory conditions both in humans and animals could only be efficiently alleviated by stimulating acupuncture points, while in the case of treating non-acupuncture points there was no really measurable pain-killing effect observed. This is in accordance with the fact that even so-called placebo pills without active substance were only successful in killing pain in $30 \%$ of the cases. At the same time, in the cases of chronic pain this difference is not so obvious. A great number of cases is needed to achieve the statistical significance (a minimum of 122 experimental persons per examination), furthermore this issue has not been closed up to now. Also in Eory's experiments when applying the needle to points considered to have low resistance (acupuncture points are also described as having low resistance and higher impedance, see later) they were able to induce local warming on certain plants (monitored by using infra camera), while in the case of treating points without low electric resistance the plants did not react with an intense growth [2-4]. 


\section{References}

1. Pomeranz B, in Stux G, Hammerschlag R (2001) Clinical Acupuncture. Stux, Gabriel, Hammerschlag, Richard (Eds.), Scientific Basis, Springer pp. 15-35.

2. Eőry A, Kuzmann E, ÁdámGy (1970) Exact Mapping of Electrical Skin Resistance Taking into Account the Influential Factors Simultaneously (English abstract). Magyar Pszichológiai Szemle 4: 514-529.
3. Eőry A, Fischer J, Mesko A, McKenna B (1996) Factorial Designs in the Acupuncture Research: Special Features (Advantages and Limitations) Lecture Held at "What To Do If a Randomized Trial Is Not Possible?" International Symposium, Project Münchener Modell, Munich, Germany. In the Abstract Book on page 15.

4. Eőry A (1984) In Vivo Skin Respiration (CO2) Measurements in the Acupuncture Loci. Acupuncture and Electro-Therapeutics Research 9(4) : 217-223.

\section{Your next submission with Juniper Publishers} will reach you the below assets

- Quality Editorial service

- Swift Peer Review

- Reprints availability

- E-prints Service

- Manuscript Podcast for convenient understanding

- Global attainment for your research

- Manuscript accessibility in different formats ( Pdf, E-pub, Full Text, Audio)

- Unceasing customer service

Track the below URL for one-step submission https://juniperpublishers.com/online-submission.php 